\title{
The Financial Trilemma and Macroeconomic Instability: Empirical Evidence from Kenya
}

\section{Lucas K. Njoroge}

Senior Economist, Comesa Monetary Institute (CMI), P.o Box 12301-00100, Nairobi, KENYA

*E-mail for correspondence: 1knjoroge@yahoo.com

Cell Phone: +254720459004

Received: Jun 12, 2015;

Accepted: Jun 20, 2015;

Published: Jul 24, 2015

Source of Support: Nil

No Conflict of Interest: Declared

\begin{abstract}
The purpose of the study is to test whether the financial trilemma holds for a small open economy, and examine the implication of the implicit financial trilemma configuration on macroeconomic instability using Kenyan data. First, the study constructs the trilemma and macroeconomic instability indices and tests the financial trilemma. Second, the study empirically examines the effect of financial trilemma on macroeconomic instability. The results show that the financial trilemma does not hold for Kenya. However, by using the overall foreign participation to total equity turnover as a measure of financial openness, the trilemma indices are statistically significant. The results imply that the increasing financial openness is potentially driving the Kenyan economy towards financial trilemma characterized by a delicate balance of improving monetary independence and exchange rate stability. Financial openness is associated with increased macroeconomic instability. International reserve accumulation acts as a buffer and does not cause macroeconomic instability, implying that the Central Bank of Kenya conducted effective sterilization during the study period. This is the first study to test for the financial trilemma using Kenyan data. This study differs from other similar studies in a number of important ways. First, the study construct alternative financial trilemma indices that reflect the various reforms taking place in Kenya. Second, the study uses a unique data set based the newly released quarterly GDP data unlike most other studies that depend on annual data.
\end{abstract}

Keywords: Financial Trilemma, Openness, Macroeconomic Instability, Kenya

JEL Classifications Code: F31

\section{Background And Problem Statement}

The 2008-09 global financial and economic crises and the subsequent Euro debt crisis have brought into sharp focus the role of Financial Trilemma in understanding the policy mix challenges facing not only emerging markets but also small open low-income economies. The Financial Trilemma is one of the important implications of the Mundell-Fleming macroeconomic framework where a country may not simultaneously target the exchange rate, conduct an independent monetary policy, and have full financial integration. Policy makers face a trade-off, where increasing one policy variable induces a drop in the weighted average of the other two variables. Most of the empirical literature on the Financial Trilemma focuses on developed or emerging market economies (Aizenman et al. 2008, 2010 and 2011; Obstfeld, et al. 2010). However, we are now seeing small open economies juggling different policy mixes, congruent to the Financial Trilemma to deal with increased short-term financial flows and exchange rate volatility.
Similar to other small open economies, Kenya is relatively less integrated with the developed financial markets, but this is changing. Over the last five years, overall foreign participation to total equity turnover in the Nairobi Securities Exchange (figure 1) has increased to an average of over 50 percent from below 20 percents in the earlier years. Kenya also floated a sovereign bond in 2014 which was massively oversubscribed and at a lower cost. The Bond was oversubscribed attracting US dollars 8.8 billion, slightly more than four times the US dollars 2 billion the government was seeking. Kenya's increased financial openness is desirable as it allows international risksharing. However, financial openness has also led to increased exposure to capital flight and exchange rate instability. Consequently, Kenya intervenes in the foreign exchange market to stem excessive volatility of the shilling but generally allows the exchange rate to respond to market pressures (figure $2 a$ and $2 b$ ).

Kenya has gone through periods of macroeconomic instability as evident through the recent episodes of exchange rate volatility and high inflation. In 2011, Kenya 
experienced significant inflationary pressures, higher exchange rate volatility, capital outflows, and loss of reserves. Monetary easing in the preceding period seems to have encouraged capital flight, putting unwanted pressure on foreign exchange markets and potentially eroding reserves. The policy response through monetary tightening drastically changed the scenario in 2012 - 2013, as capital inflows began surging again, exchange rates stabilizing and inflationary pressures diminishing. Kenya is increasingly depending on the key policy interest rate to influence macroeconomic outcomes. The Central Bank of Kenya (CBK) uses the Central Bank Rate (CBR) to signal the stance of monetary policy. In 2015, the Kenya shilling has come under immense pressure to depreciate against major world currencies and especially against the US dollar partly due to the imminent normalization of monetary policy in the United States. Consequently, the Central Bank of Kenya increased the Central Bank Rate (CBR) by 150 basis points to 10 percent. These policy choices seem to suggest that policy makers in Kenya could be dealing with the "Impossible Trinity" or the "Trilemma".

Deciding on appropriate policy mix remains a challenge and an empirical issue especially for small open economies with open capital accounts and floating exchange rates. The openness of the capital account means that Kenya like other emerging market economies remain vulnerable to slowdowns or sudden stops in private financial inflows. This could be triggered by global re-pricing of risk or domestic shocks and hence further perpetuate exchange rate volatility. Kenya also face; the possibility of capital reversals that could follow the US normalization of monetary policy, weakening current account balance following huge FDI-financed investment in infrastructure and natural resources, and declining commodity prices, all presenting daunting macroeconomic policy challenges for the country. Kenya is undertaking its first most ambitious infrastructure project of constructing a Standard Gauge Railway (SGR) with phase one of the project $(472 \mathrm{Km}$ between Nairobi and Mombasa) currently underway.

It is, therefore important to understand how Kenya's policy choices have been influenced by financial openness. The paper, therefore, answers the following questions:

- To what extent does the Financial Trilemma configuration apply to Kenya?

- Does reserves accumulation affect Kenya's macroeconomic policy choices? and,

- What is the effect of the evolving Financial Trilemma configuration on Kenya's macroeconomic instability?

There exists a voluminous theoretical and empirical literature on these issues but mostly not for less developed countries (Aizenman, et al. 2011 and 2010). The debate remains inconclusive owing to country idiosyncratic characteristics and paucity of data. This study answers these questions by developing alternative indices for the Financial Trilemma tailored to the experiences of small open economies. Kenya provides variable lessons for other small open economies that face increasing financial flows that seem to be a threat to their macroeconomic stability.

\section{LITERATURE REVIEW}

The theoretical underpinning of the Financial Trilemma is traced to the independent seminal contributions of Mundell (1963) and Fleming (1962). The MundellFleming model, is based on simple assumptions in which a small open economy chooses between three policy goals of free capital mobility, a fixed exchange rate and a monetary policy devoted to domestic objectives. A country may simultaneously choose any two, but not all, of the three goals. In particular, if the capital account is closed, domestic interest rates transmit to domestic demand, irrespective of the exchange rate regime. However, with an open capital account, the extent of monetary autonomy will be determined by the exchange rate regime and the degree of substitutability between domestic and foreign financial assets. Under a floating exchange rate regime, monetary policy works either through the interest rate and liquidity channel or through the exchange rate channel. Under the exchange rate channel, the effectiveness of monetary policy is larger if domestic and foreign assets are substitutes; as policyinduced changes in interest rates affect the exchange rate, which in turn affects output and inflation. However, under a fixed exchange rate regime, monetary policy is rendered impotent the higher the degree of substitutability between domestic and foreign assets through capital flows (Frankel, J. et al. 2004).

The empirical evidence remains diverse and mixed on each of the three policy choices (Combes et al. 2011 and Obstfeld, 2009). Monetary independence has been associated with stable and sustained economic growth. However, with prices and wages rigidities, policy makers could also manipulate output leading to increasing output and inflation volatility. Monetary authorities could also abuse their autonomy to monetize fiscal debt and, therefore, end up destabilizing the economy through high and volatile inflation (Aizenman, et al. 2009). On one hand, exchange rate stability leads to price stability through mitigating uncertainty and anchoring expectations, thereby promoting investment and international trade. Exchange rate stability also tends to enhance policy credibility and contribute to output stability. On the other hand, exchange rate stability could be at the detriment of the economy's ability to respond adequately to external shocks through exchange rate adjustments. Exchange rate rigidities could make an economy prone to asset booms and bust and hence cause misallocation of resources and unbalanced, unsustainable growth (Prasad, 2008). Similarly, financial liberalization has ambiguous outcomes. On one hand, access to international capital markets leads to among others, portfolio diversifications, risk sharing, and more efficient resource allocation, which ultimately promotes economic 
growth. On the other hand, financial openness could expose economies to volatile cross-border capital flows that could lead to sudden stops and reversals of capital flows and consequently boom-bust cycles and economic instability (Kaminsky and Schmukler, 2002). Besides the three ways of pairing two out of the three policies, the effect of the policy choice can differ depending on what the other policy choice it is paired with and hence the need for country specific empirical analysis (Obstfeld et al. 2005 and Aizenman, 2010 and 2011).

Aizenman and Glick, (2009) show that the link between hoarding reserves and financial integration provides a fourth dimension to the Trilemma especially in emerging markets that are only partially integrated with the global financial system, and where sterilization is heavily used to manage the potential inflationary effects of hoarding reserves. Hoarding reserve acts as a buffer, reducing the odds and severity of sudden stops and capital flight crisis. Hoarding and managing reserves in the short-run increases financial stability and capacity to run independent macroeconomic policies (Kohli, 2011). On the contrary, most industrial countries keep their reserves/GDP ratios low because they can easily access international financial markets in case of an urgent need for foreign currencies. Also industrial countries have the ability to borrow externally in their currencies (Chinn and Ito. 2008, 2006).

A study on the Financial Trilemma for a small open economy like Kenya can be justified on a number of grounds. Most small open economies are experiencing increased capital flows which have made exchange rate management a challenge. With increased openness to the rest of the world, these economies continue to experience excess volatility of exchange rates and capital flight. Central banks are increasingly being forced to intervene in the foreign exchange market, and macroeconomic policy management has become more complicated, with challenges similar to these of the financial trilemma.

\section{Methodology And DatA}

The methodology applied in the study departs from the previous approaches (such as, Aizenman et al. 2008, 2010 and 2011) by constructing Financial Trilemma indices that reflect the characteristics of a small open economy.

\section{MonetARY INDEPENDENCE (MII) INDEX}

Following Aizenman et al. (2008, 2010 and 2011), the Monetary Independence (MI) Index is measured as the reciprocal of the correlation of quarterly interest rates in the home country and the base country (the United States). The MI index for the extent of monetary independence is defined as:

$M I=1-\frac{\operatorname{corr}\left(i_{a}-i_{b}\right)-(-1)}{1-(-1)}$

where $a$ refers to the home country and $b$ to the base country. The maximum value of $\mathrm{MI}$ is 1 , and the minimum value is 0 . Higher values of the index mean more monetary policy independence.

The MI index has been criticised on the grounds that when the interest rates are constant over a period (in this case a quarter), the correlation between home and base countries rates is undefined (which is treated to be equal to zero) and makes MI $=0.5$ (Aizenman et al. 2010). This does not necessarily imply monetary policy independence but could reflect other factors such as the use of other tools to implement monetary policy instead of manipulating the interest rates, among others.

We modify equation 1 by using the central bank rate or the 91-day Treasury bill rate for ia. The central bank rate (CBR) has recently gained prominence as the key policy rate that coordinates movements in short-term interest rates in Kenya while the 91-day Treasury bill rate is the risk-free rate. $i b$ is the policy rate of the base country, which in Kenya's case is the US policy rate. A base country is a country whose policy rate has the greatest influence on the home country monetary policy (in this case the US). The value for modified MI is denoted as MII and ranges between 0 and 1 where the higher the value, the more is monetary policy independence. The value of $\mathrm{MII}_{\mathrm{t}}$ is determined by the most robust results from either using the 91-day Treasury bill rate or the Central Bank Rate.

\section{EXCHANGE RATE STABILITY INDEX (EI)}

The Exchange Rate Stability (ESI) index developed by Aizenman et al. (2008, 2010 and 2011) is based on standard deviations of the domestic exchange rate to the US dollar. The EI is computed as:

$$
E I=\frac{0.01}{0.01+\operatorname{std} v(\Delta(\log (\text { exrate })} \quad . .2
$$

The EI index is normalized to range between 0 to 1 and the higher the value, the greater is the exchange rate stability. However, EI index has been criticized for creating a downward bias by exaggerating the flexibility of the exchange rate. When the rate follows a narrow band, but is devalued or revalued infrequently such that the average change in the exchange rate become so small that even small changes makes the standard deviation big, the exchange rate stability value tends to be very small (Aizenman et al. 2010).

Following the study by Combes et al. (2011), we construct an alternative exchange rate stability index as follows:

$$
E I I_{t}=\% \Delta q_{t} /\left(\% \Delta q_{t}-\% \Delta R V_{t}\right) \quad . .3
$$

Where $\Delta \mathrm{q}_{\mathrm{t}}=\left|\frac{\text { exrate }_{\mathrm{t}}-\text { exrate }_{\mathrm{t}-1}}{\text { exrate }_{\mathrm{t}-1}}\right|$ and ext is the nominal exchange rate of Kenya shilling to the US dollar during time $t$, and $\% \Delta q_{t}$ is the relative variation of the nominal exchange rate expressed as a percent. $\Delta \mathrm{RV}_{\mathrm{t}}=\left|\frac{\mathrm{RV}_{\mathrm{t}}-\mathrm{RV}_{\mathrm{t}-1}}{M B_{\mathrm{t}-1}}\right|$ and $R V_{t}$ represent international reserve assets, $M B_{t}$ the 
monetary base at time $\mathrm{t}$ and $\% \Delta \mathrm{RV}$ is the relative variation in reserves expressed as a percent.

This index is justified because exchange market pressure emanates from the relationship between the nominal exchange rate and relative foreign reserves holdings. In case of a pure floating system with no intervention and no reserves (), then EII =1, reflecting maximum flexibility, with the exchange rate allowed to float freely. Conversely, a fixed exchange rate means that and hence $E I I=0$ and the changes in the index reflect only changes in reserves through monetary authorities' interventions. Cases in between imply less exchange rate flexibility or more intervention in the foreign exchange market. Care must be taken when interpretation the EII compared with EI. Although EII also ranges between 0 and 1, as opposed to EI above, the lower the value, the greater is the exchange rate stability.

\section{FINANCIAL OPENNESS INDEX (FOI)}

Following Aizenman and Rajeswari (2011) and Aizenman et al. (2008, 2010 and 2011), financial openness is captured by the capital openness index based on the ratio of the sum of inward and outward foreign investment flows to GDP (in particular, FDI and Portfolio). The Financial Openness Index is limiting and may not capture the important reforms that Kenya has been pursuing both at home and as an initiative within the East African Community. Instead, this study views financial openness from three distinct ways. First is openness of the stock market to foreign investors. Recently, the Nairobi securities exchange (NSE) has seen increased participation of foreigners following various reforms in the sub-sector. These reforms include, among others; live trading on the automated trading systems, demutualization of the NSE, removal of the block trades board and the introduction of the functionality for the trading of rights in the same manner as equities, and the implementation of the Wide Area Network (WAN) platform. We calculate openness to the stock market as the percentage of overall foreign participation to total equity turn over (FPET) in the Nairobi Securities Exchange. Second is openness to foreign direct investments (FDI). Openness to FDI, denoted by FDIGDP, is measured using the sum of absolute values of FDI inflows and outflows as a share of Gross Domestic Product (GDP) and includes equity capital, reinvestment earnings, other long -term capital and short-term capital. Finally is the openness to gross private capital flows denoted by GPVTFGDP and calculated as the sum of the absolute values of direct, portfolio, and other investment inflows and outflows as a ratio of GDP.

According to Aizenman et al. (2008, 2010 and 2011), the three indices represent a binding trade-off between the three policy objectives where an increase in any one of the three indices has to be balanced by a corresponding decrease in one or two of the other indices, so that the constraint can be binding. When all three goals are simultaneously desirable, then whichever index has a higher value represents the policy objective that authorities want to focus on more. The principle of tradeoff among the Trilemma policy goals can be captured by:

Constant $=a(M I I)_{t}+b(E I)_{t}+c(F O I)_{t}+\mu_{t} \quad . .4$

Where MI is the Monetary Independence Index, EI is Exchange Rate Stability Index, and FOI is the Financial Openness Index. The estimated coefficients of equation 4 show the weights attached by policy makers to the three policy goals. A high goodness of fit $\left(\mathrm{R}^{2}\right)$ suggests that a linear specification is robust enough to explain the tradeoff faced by policy makers among the three policy objectives.

\section{EfFect OF Trilemma ChOICES ON MACROECONOMIC INSTABILITY}

We examine empirically how various choices regarding the three policies affect macroeconomic instability. The discussion of the Financial Trilemma ultimately should provide the possible implication of the policy choices on macroeconomic instability. That is, does country policy choices as may be dictated by the Financial Trilemma fuel or dampen macroeconomic instability? The objective is to analyze the impact of the trilemma configurations on macroeconomic instability, and to investigate whether reserves accumulation affects macroeconomic policy dynamics, in a small open economy.

In particular, the model to be estimated is given as:

$y_{t}=\beta_{0}+\beta_{1} F T_{t}+\beta_{2}\left(\frac{R V}{G D P}\right)_{t}+\beta_{3}\left[F T *\left(\frac{R V}{G D P}\right)\right]_{t}+\beta_{5} Z_{t}+\mu_{t} . .5$

where, $y_{t}$ is a measure for macroeconomic instability calculated using quarterly data. $\mathrm{FT}_{\mathrm{t}}$ is a vector of any two of the three Financial Trilemma indices, namely, MII, EII, and FOI. The use of any two of the indices besides conforming with the Financial Trilemma, is important an important consideration in order to avoid the dummy variable trap. (RVGDP) $\mathrm{t}$ is the level of reserves as a ratio to GDP. Also included is an interaction term $\left[\mathrm{FT}_{\mathrm{t}}\right.$ *(RVGDP $\left.)_{t}\right]$ between the Trilemma indices and the RVGDP to assess whether reserves complements or substitutes other policy stances. $Z_{t}$ is a vector of macroeconomic instability determinants which includes the output growth (measured by quarterly growth rate of real GDP) and money growth rate (measured by quarterly growth rate of money supply M3). Most other determinants of macroeconomic instability are used in the construction of the macroeconomic instability index $\left(\right.$ INST $\left._{t}\right)$ and therefore are not directly included in the estimation of equation 5, in order to avoid a host of econometric problems such as multicollinearity and autocorrelation, among others.

A composite macroeconomic instability index (INST $t)$ is constructed as follows: 
$I N S T_{t}=\frac{\ln \left(\frac{\text { cpi }_{t}}{\text { cpi } i_{t-1}}\right)}{\delta_{\Delta \ln (c p i)}}+\frac{\ln \left(\frac{\text { exrate }_{t}}{\text { exrate }_{t-1}}\right)}{\delta_{\Delta \ln (\text { exrate })}}-\frac{\ln \left(\frac{\text { fbal }_{t}}{\text { fbal }_{t-1}}\right)}{\delta_{\Delta \ln (\text { fbal })}}+\frac{\ln \left(\frac{C A B_{t}}{C A B_{t-1}}\right)}{\delta_{\Delta \ln (C A B)}} . .6$

Where cpi is the consumer price index, exrate is the exchange rate of the Kenya shilling to the U.S. dollar, fbal is the fiscal balance, $\mathrm{CAB}$ is the current account balance and is the standard deviation of each variable. The choice of these variables is based on the influence that they have in distorting internal and external balance of an economy. The stress on internal balance is proxied by the cpi variable that capture the effect of inflationary pressures, and the fiscal balance variable that capture macroeconomic instability that emanate from excessive deficits. The stress on external balance is proxied by the exrate variable that captures exchange rate pressures, and the $\mathrm{CAB}$ variable that captures macroeconomic stress emanating from current account deficit. Higher levels of INST indicate increased macroeconomic instability. This index provides some insights on how policies are combined to manage macroeconomic instability.

\section{Data Characteristics And Sources}

The study uses quarterly data over the period 2000Q1 to 2013Q4. The main sources of data for the study are the Central Bank of Kenya (CBK) and the Kenya National Bureau of Statistics (KNBS). The paper use quarterly average of 91-day treasury bills rate and the Central Bank Rate. The average 3-month LIBOR rate in US dollars and the US policy rate are used to construct the quarterly monetary independence index. The monthly series Kenya shilling US dollar exchange rates are used to compute the quarterly exchange rate stability index. Data on FDI, FPET, and GPVTFGDP is used to compute the quarterly financial openness index (FOI). Computation of quarterly macroeconomic instability index is based on data on monthly average Kenya shilling exchange rate to the US dollar, monthly imports of goods and services, quarterly fiscal balance, and quarterly nominal GDP. The analysis of the impact of Reserves on macroeconomic instability is based on quarterly data on gross official foreign exchange reserves as a percentage of GDP. Appendix 1 provides detailed data description and sources.

The time series nature of these data means that we must establish the characteristics of the various series. We conducted unit root tests for all our variables and established that they are all integrated of order one, I(1) except for the indices that are stationary. We applied the Augmented Dickey Fuller (ADF) Tests and did robustness check using Kwiatkowski-Phillips-Schmidt-Shin (KPSS) test. KPSS is a more powerful test than ADF when $\rho$ is close to one..This means that the regressions from the models are prime candidates for spurious regression, and conventional inferences under the stationarity assumption would be invalid. However, after testing for cointegration for equations 4 to 6 , we find that the variables are cointegrated in each of the equations. We applied the Engle-Granger Two- step procedure and did robustness check using the Dynamic OLS cointegration method (DOLS). Unlike the Engle-Granger method, DOLS allows making inferences on the individual elements of the cointegrating relations. The results of these tests have not been reported in the paper but can be provided on request. As demonstrated by Stock and Watson (1993), if two or more variables are cointegrated, then the OLS estimates of the coefficients in the cointegrating regressions are consistent. In the following section, therefore, we only report results of the level equations/ cointegrating regressions since cointegration is established for all our models (equations 4 to 6) and hence the respective parameter estimates are consistent.

\section{EMPIRICAL RESULTS}

Test for the Financial Trilemma

Table 1: Estimated regression for the Financial Trilemma

\begin{tabular}{llll}
\hline Variables & $\begin{array}{l}\text { Equation7: } \\
\text { FOI=GPVTFGDP }\end{array}$ & $\begin{array}{l}\text { Equation8: } \\
\text { FOI=FDIGDP }\end{array}$ & $\begin{array}{l}\text { Equation9: } \\
\text { FOI=FPET }\end{array}$ \\
FOI & $\begin{array}{l}0.115333^{* * *} \\
(0.006966)\end{array}$ & $\begin{array}{l}0.115471^{* * *} \\
(0.006632)\end{array}$ & $\begin{array}{l}0.303320^{* *} \\
(0.177034)\end{array}$ \\
& & & \\
EII & 0.142054 & 0.128255 & $0.207234^{*}$ \\
& $(0.088430)$ & $(0.087894)$ & $(0.118078)$ \\
& & & \\
MII & 0.096371 & $0.122597^{*}$ & $0.229385^{*}$ \\
& $(0.059642)$ & $(0.069272)$ & $(0.013893)$ \\
& & & \\
$\boldsymbol{R}^{2}$ & 0.10 & 0.12 & 0.24 \\
$*, * * * * *$ & denotes statistical significance at 10 percent, 5 percent, \\
and 1 percent respectively. Standard errors are in parentheses.
\end{tabular}

The estimation of equation 4 gives the results in Table 1 and shows the empirical test for the Financial Trilemma configuration. The three equations show results when the financial openness index variable is gross private capital flows to GDP ratio - GPVTFGDP (equation 7) or Foreign Direct Investment to GDP ratio - FDIGDP (equation 8) or the percentage share of overall foreign participation to total equity turnover ratio - FPET (equation 9). Overall, the financial openness index is the most significant variable in all the three equations indicating that Kenya pays more attention to financial integration. This implies that increasing interest in Nairobi Securities Exchange by foreign investors is pushing Kenya closer to the Financial Trilemma configuration.

Contrary to the results of other emerging market economies, the relatively low R-squared in all the three equations, however, suggests lack of support for the Financial Trilemma in Kenya. The three policy goals, though with the expected positive sign, are not linearly related to each other, suggesting that policy makers in Kenya are currently not facing the trilemma trade off. Alternatively, the results may be interpreted to mean that the relatively under developed state of Kenya's capital market could be hampering the extent to which the Central Bank Rate (CBR) fully reflect the stance of monetary policy, implying weak transmission mechanism of monetary policy. The results are consistent with Davoodi et al. (2013), 
who finds considerable lags and weak transmission mechanisms of monetary policy in Kenya. The high risks premiums associated with low-incomeemerging market economies could also be contributing to the failure of the financial trilemma. With high-risk premiums, foreign investors do not consider Kenya's domestic assets as perfect substitutes for foreign assets.

A closer look at equation 9 (Table 1) that uses the overall foreign participation to total equity turnover ratio as a measure of financial openness index, however, shows that all the trilemma indices are statistically significant albeit marginally at a low of 10 percent level except for the financial openness index that is significant at 5 percent level. The financial openness index is also consistently significant in all the three equations. The results suggests that foreign investors are taking advantage of the various reforms and vibrancy of the Nairobi Securities Exchange, and seem to be driving Kenya closer to policy trilemma choice as financial integration with the rest of the world increases. Albeit at low R-squared (implying that the Financial Trilemma does not hold) policy makers in low-income emerging market economies with open capital account and vibrant stock markets may need to closely monitor the developments in their capital markets to avoid sudden stops or reversals of capital flows especially now that the US Federal Reserve is normalizing monetary policy. For robustness check, we chart the trilemma indices in the diamond graphs under figure 4 (a) to (c). We have added a fourth dimension on the policy configuration to take care of reserve accumulation. Reserve accumulation allows policy makers more room for maneuver when faced with shortterm trade-off between monetary independence and exchange rate flexibility. Consistent with the results in Table 1, the diamond graphs suggest that monetary autonomy is increasingly becoming important as the role of Central Bank Rate (Kenya's policy rate) as a signalling rate for all other market rates of interest gain traction.

Financial integration seems important only when measured by the share of foreign participation in total equity turnover as depicted in figure 3 (c). However, the important role played by reserves accumulations in ensuring exchange rate stability imply that exchange rate stability is also gaining importance as these economies become more integrated with the rest of the world. The descriptive results are consistent with findings for broader group of emerging market economies where the policy combination of exchange rate stability and financial openness seems to have dominated policy choice over the past two decades (Aizenman et al. 2008).

In sum, Kenya appears to be moving towards a Financial Trilemma characterized by active intervention in foreign exchange market (Figure 1 depicts CBK participation in foreign exchange market). Congruent to experiences from other emerging middle-income economies, Kenya seem to have accelerated financial openness as measured by share of foreign participation in the NSE but reduced monetary independence. The current aggressive accumulation of foreign exchange reserve suggests some improvement in monetary autonomy. Kenya has also been increasing the ratio of reserves to GDP as financial integration improves (figure 2).

\section{EFFECT OF FINANCIAL TRILEMMA ON MACROECONOMIC INSTABILITY}

In this section, we empirically examine whether the Financial Trilemma indices causes macroeconomic instability in Kenya. The computation and inclusion of a composite index for macroeconomic instability provides an important contribution of this study and a departure from the earlier studies such as Aizenman et al. (2008, 2010 and 2011), that only use inflation as a measure of macroeconomic instability. Macroeconomic instability in small open lowincome economies emanates from pressures in internal and external balance variables. A macroeconomic instability index is more relevant to such economies than just inflation since various external and internal shocks affects the developments in the current account balance, fiscal balance and exchange rate, which are equally important sources of macroeconomic instability.

Beside the reserves variable, we consider two other control variables most frequently used in the literature- the output growth (measured by quarterly growth rate of real GDP) and money growth rate (measured by quarterly growth rate of money supply M3). We do not include any other control variable due to limited degrees of freedom and because the other controls are mostly relevant for cross-country estimations. The choice of variables is also consistent with similar approaches in the literature on the impact of trilemma indices to macroeconomic outcomes. The results are reported in Table 2 .

Table 2: Results on the Impact of Trilemma Policy choices on Macroeconomic Instability- Dependent variable: Macroeconomic Instability (Inst)

\begin{tabular}{|c|c|c|c|c|c|c|}
\hline $\begin{array}{l}\text { Trilemma } \\
\text { Variables }\end{array}$ & (1) & (2) & (3) & (4) & (5) & (6) \\
\hline FOI- FPET & $\begin{array}{c}0.385^{* * *} \\
(0.140)\end{array}$ & \begin{tabular}{|l}
$0.637^{* * *}$ \\
$(0.203)$
\end{tabular} & $\begin{array}{l}0.102^{* * *} \\
(0.036)\end{array}$ & $\begin{array}{l}0.643^{* * *} \\
(0.221)\end{array}$ & & \\
\hline$\overline{\mathrm{MIIPR}}$ & $\begin{array}{c}0.100^{* * *} \\
(0.036)\end{array}$ & $\begin{array}{l}0.091^{\text {** }} \\
(0.037)\end{array}$ & & & $\begin{array}{l}0.327^{*} \\
(0.174)\end{array}$ & $\begin{array}{c}0.204 \\
(0.276)\end{array}$ \\
\hline EII & & & \begin{tabular}{|c|}
0.538 \\
$(0.467)$ \\
\end{tabular} & $\begin{array}{l}0.018^{* *} \\
(0.008)\end{array}$ & $\begin{array}{c}0.012 \\
(0.096)\end{array}$ & $\begin{array}{c}0.262 \\
(0.164) \\
\end{array}$ \\
\hline \multicolumn{7}{|l|}{$\begin{array}{l}\text { Interaction } \\
\text { Terms }\end{array}$} \\
\hline FOI* RVGDP & & $\begin{array}{c}-0.027^{* *} \\
(0.011) \\
\end{array}$ & & $\begin{array}{l}-0.219 \\
(0.170) \\
\end{array}$ & & \\
\hline$\overline{\text { MIIPR* RVGDP }}$ & & $\begin{array}{l}-0.028^{*} \\
(0.014) \\
\end{array}$ & & & & $\begin{array}{c}-0.212 \\
(0.272) \\
\end{array}$ \\
\hline EII*RVGDP & & & & \begin{tabular}{|c}
$-0.018^{* *}$ \\
$(0.009)$ \\
\end{tabular} & & \begin{tabular}{|c}
$-0.506^{* *}$ \\
$(0.245)$ \\
\end{tabular} \\
\hline \multicolumn{7}{|l|}{$\begin{array}{l}\text { Other } \\
\text { Variables }\end{array}$} \\
\hline RVGDP & $\begin{array}{c}0.193 \\
(0.626) \\
\end{array}$ & $\begin{array}{c}0.186 \\
(0.142) \\
\end{array}$ & \begin{tabular}{|c|}
0.175 \\
$(0.707)$ \\
\end{tabular} & $\begin{array}{c}0.605 \\
(0.409) \\
\end{array}$ & $\begin{array}{c}0.606 \\
(0.867) \\
\end{array}$ & $\begin{array}{c}0.198 \\
(0.141) \\
\end{array}$ \\
\hline OutputG & $\begin{array}{c}-0.102^{* * *} \\
(0.037)\end{array}$ & $\begin{array}{c}-0.665^{* * *} \\
(0.203) \\
\end{array}$ & \begin{tabular}{|c}
$-0.027^{* *}$ \\
$(0.011)$ \\
\end{tabular} & $\begin{array}{c}-0.385^{* * *} \\
(0.140) \\
\end{array}$ & $\begin{array}{c}-0.550^{* * *} \\
(0.200) \\
\end{array}$ & \begin{tabular}{|c}
$-0.602^{* * *}$ \\
$(0.217)$ \\
\end{tabular} \\
\hline M3G & $\begin{array}{l}0.084^{* *} \\
(0.035)\end{array}$ & $\begin{array}{r}0.168 \\
(0.373) \\
\end{array}$ & $\begin{array}{c}0.925 \\
(0.861) \\
\end{array}$ & $\begin{array}{l}0.161^{*} \\
(0.086)\end{array}$ & $\begin{array}{c}0.146 \\
(0.260) \\
\end{array}$ & $\begin{array}{l}0.344^{*} \\
(0.173) \\
\end{array}$ \\
\hline R-Squared & 0.661 & 0.742 & 0.705 & 0.775 & 0.723 & 0.791 \\
\hline
\end{tabular}

$* * * * * *$ denotes statistical significance at 10 percent, 5 percent, and 1 percent respectively. Standard errors are in parentheses. 
The results in columns 1,3 and 5 are the baseline estimates for equation 5 without the interaction terms. Columns 2, 4 and 6 estimate equation 5 including the interaction terms. The monetary independence index (MIIR) show a positive relationship (in row 3) with macroeconomic instability indicating the increasing reliance on the Central Bank Rate (CBR) as the key signaling rate for monetary policy. The CBR has recently enhanced Central Bank of Kenya's ability to influence macroeconomic outcomes. For instance in 2011, the Central Bank of Kenya was able to tame inflationary spike and exchange fluctuations by instituting a decisive monetary policy tightening that saw the CRB increased by over 200 percent. Similarly, in June 2015, Central Bank of Kenya raised the CBR by 150 basis points to 10 percent to support the shilling that has been under a lot of pressure to depreciate since January 2015. We notice that in column 6, MIIR is not significant possibly indicating the opposing effect of the interaction term (MIIR*RGDP) which lenders the two effects impotent.

The financial openness index (FOI-FPET) is positively and statistically significant in all the equations indicating that financial openness is associated with increased macroeconomic instability. For most small open economies, macroeconomic instability follows from the likely surge in capital inflows that could lead to asset price spikes in the equities markets and real estate. The resultant speculative tendencies in these markets could lead to asset booms, bubbles and bursts with unprecedented macroeconomic instability. In Kenya, capital inflows are associated with increased reserves accumulation through sterilized intervention by the Central Bank of Kenya (CBK) in the foreign exchange market. Such sterilized interventions means that the transmission into higher prices and associated macroeconomic instability is minimal which could explain interaction term (FOI* RVGDP) in column 2 being negative but significant.

The exchange rate stability index in all the estimations except one is positive and insignificant (EII declining) implies that Kenya does not prioritize exchange rate stability over the other two policy trilemma variables. This is consistent with Central Bank of Kenya exchange rate policy that advocates for a freely floating regime with interventions only restricted to managing excessive volatility of the exchange rate. However, we notice in column 4, a statistically significant coefficient of the exchange rate stability index that is justified by the presence in the equation of the interaction term EII*RVGDP. The negative sign of the interaction term indicate that greater exchange rate stability is associated with lesser macroeconomic instability (inst declining), justifying the accumulation of foreign exchange reserves to mitigate volatility.

The coefficient of international reserve to GDP ratio (RVGDP) is positive and statistically insignificant across all the estimated equations, suggesting that the accumulation of reserves did not caused macroeconomic instability. Alternatively, this could mean that Kenya managed to sterilize effectively and therefore prevented macroeconomic instability that could emanate from spill over effects of reserves accumulation through high domestic prices. The could be reflecting the strong presence of the Central Bank of Kenya in both the foreign exchange market to build reserves and the money market through active participation in open market operations during the period under study. The actual implementation of such a double-edged approach to reserve accumulation may mean diverse degree of successes for sterilization from one small open economy to another.

The output growth variable show negative and statistically significant coefficients, indicating that high economic growth have a stabilizing effect during period of macroeconomic instability. The money growth variable indicates a positive but not always significant effect on macroeconomic instability reflecting its positive influence during periods of high inflation.

\section{CONCLUSION}

The study set to test whether the Financial Trilemma holds for a small open economy using Kenyan data. The study also examines the implication of the implicit Financial Trilemma configuration on macroeconomic instability. First, the results of empirical investigation show that the Financial Trilemma does not hold for Kenya, possibly reflecting the relatively less developed capital market and high-risk premiums that may not permit perfect substitutability of foreign and domestic assets. However, by using the overall foreign participation to total equity turnover as a measure of financial openness in the trilemma configuration, the results suggest that the trilemma indices are statistically significant albeit marginally and still at very low Rsquared. That is, the increasing financial openness is potentially driving the economy towards a Financial Trilemma characterized by a delicate balance of improving monetary independence and exchange rate stability in the face of increasing financial integration. This implies that foreigners are taking advantage of the various reforms and the vibrancy of the Nairobi Securities Exchange (NSE) to invest in the exchange. This could be driving Kenya closer to a Financial Trilemma as the economy gets more integrated with the rest of the world. The results are also consistent with the Diamond graphs of the Financial Trilemma in figure 4.

Second, on the influence of the Financial Trilemma on macroeconomic instability, the results show that financial openness index (FOI-FPET) is positively and statistically significant in all the equations indicating that financial openness is associated with increased macroeconomic instability. Greater exchange rate stability is also associated with macroeconomic stability justifying accumulation of foreign reserves to mitigate the excessive volatility of the Kenya Shilling exchange rate. However, the results show that Kenya does not prioritize exchange rate stability over the other two Financial Trilemma 
variables. This is consistent with Central Bank of Kenya exchange rate policy that advocates for a freely floating regime with interventions only restricted to managing excessive volatility of the exchange rate. Finally, international reserve accumulation acts as a buffer and does not cause macroeconomic instability, implying that the Central Bank of Kenya conducted effective sterilization during the study period.

A key implication of the results is that even as Kenya leans towards financial integration, financial openness is exposing the country to macroeconomic instability. This call for caution and close monitoring of the developments in the securities exchange to identify any early warning of possible sudden stops or reversals of capital flows to avoid would be disruptive macroeconomic instability. The study recommends among others, a cautious approach to financial integration to ensure fewer disruption effects in case of sudden stops or reversals of capital flows. Managing and maintaining reserves above 4 months of import cover as required by regional commitments, will go a long way in providing the requisite buffer that ensures these economies strike a balance in the choice of the financial trilemma configuration. For instance, East African Community and the Common Market for Eastern and Southern Africa (COMESA) both require members' countries to have gross official reserves of over 4 months of import cover as part of their macroeconomic convergence criteria.

Efforts to make Central Banks more effective in influencing macroeconomic outcomes including moving towards Inflation Targeting (IT) frameworks are encouraged and consistent with the current reality in most of these economies. Small open economies should ensure more proactive reserve management and hoarding; possibly accumulate reserves to over six months of import cover, if this transition is to be smooth and devoid of macroeconomic instability.

\section{Reference}

Abiad, A., Detragiache, E, and T. Tressel. (2008), "A New Database of Financial Reforms," IMF Working Paper, $\mathrm{WP} / 08 / 266$.

Aizenman, J. (2011), "Trilemma and Financial Stability Configurations in Asia," ADBI Working Paper Series, No. 317

Aizenman, J. and Rajeswari, S. (2011), "The Financial Trilemma in China and a comparative analysis with India," Munich Personal RePEc Archive (MPRA) Paper No. 39798.

Aizenman, J., Chinn, M.D. and H. Ito. (2010), “The Emerging Global Financial Architecture: Tracing and Evaluating the
New Patterns of the Trilemma's Configurations," Journal of International Money and Finance (29) 4: 615-641.

Aizenman, J., Chinn, M.D. and H. Ito. (2011), "Surfing the Waves of Globalization: Asia and

Chinn, M. D. and H. Ito. (2006), "What Matters for Financial Development? Capital Controls, Institutions, and Interactions," Journal of Development Economics 81(1): 163192(October).

Chinn, M. D. and H. Ito. (2008), "A New Measure of Financial Openness," Journal of Comparative Policy Analysis 10(3): 309-322.

Combes, J., Kinda, T., and Plane, P. (2011), "Capital Flows, Exchange Rate Flexibility, and the Real Exchange Rate," IMF Working Paper, WP/11/9.

Davoodi, H., Dixit, S., and Pinter G. (2013), “Monetary Transmission Mechanism in the East African Community: An Empirical Investigation," IMF Working Paper, $\mathrm{WP} / 13 / 39$.

Financial Globalization in the Context of the Trilemma," Journal of the Japanese and International Economy (25) 3: 290-320.

Fleming, J. Marcus. (1962), "Domestic financial policies under fixed and floating exchange rates," IMF Staff Papers 9: 369-379.

Frankel, J., Schmukler, S., and Serven, L. (2004), "Global transmission of interest rates: Monetary independence and currency regime," Journal of International Money and Finance, 23 (5), 701-733.

Kohli, R. (2011), “India's Experience in Navigating the Trilemma: Do Capital Controls Help?" Indian Council for Research on International Economic Relations (ICRIER), Working Paper 257.

Kwiatkowski, D., Phillips, P., Schmidt, P., and Shin, Y (1992), "Testing the Null Hypothesis of Stationarity against the Alternative of a Unit Root: How Sure Are We That Economic Time Series Have a Unit Root?" Journal of Econometrics, 54(1-3): 159-78.

Mundell, Robert A. (1963), "Capital mobility and stabilization policy under fixed and flexible exchange rates," Canadian Journal of Economic and Political Science 29 (4): 475-485.

Obstfeld, M. (2009), International Finance and Growth in Developing Countries: What have we learned?" NBER Working Paper, 14691

Obstfeld, M., Shambaugh, J., \& Taylor, A. (2005), "The trilemma in history: Tradeoffs among exchange rates, monetary policies, and capital mobility," Review of Economics and Statistics, 87 (3), 423-438.

Obstfeld, M., Shambaugh, J.C and Taylor, A.M. (2010), "Financial Stability, the Trilemma, and International Reserves," American Economic Journal: Macroeconomics (2): 57-94.

Sedik Tahsin Saadi and Sun Tao. (2011), "Effects of Capital Flow Liberalization-What is the Evidence from Recent Experiences of Emerging Market Economies?" IMF Working Paper, WP/12/275.

Stock, J., and Watson M. (1993), "A Simple Estimator of Cointegrating Vectors in Higher Order Integrated System," Econometrica, 61(4): 783-820. 


\section{APPENDIX}

\section{Description of Data Sources}

\begin{tabular}{l|l}
\hline $\begin{array}{l}\text { Variable } \\
\text { Name }\end{array}$ & Description - Quarterly data is used and mainly sourced from the CBK and KNBS. \\
\hline CA & Current Account balance in Million US dollars \\
\hline CAB & Current account as a percentage of GDP \\
\hline CBR & Central Bank of Kenya Policy Rate as a percent \\
\hline CPI & CPI annual average \\
\hline EI & Exchange Rate Stability Index \\
\hline EII & Authors computed Exchange Rate Stability Index \\
\hline EXRATE & Kenya shillings to the US Dollar exchange rate \\
\hline Fbal & Fiscal balance defined as fiscal deficit on cash basis as a percentage of GDP \\
\hline FDIGDP & Foreign Direct Investment as a percentage of GDP \\
\hline FOI & Financial Openness Index given either as
\end{tabular}

- Openness of the stock market to foreign investors calculated as the percentage of overall foreign participation to Equity Turn over in the Nairobi Securities Exchange denoted as FPET.

- Openness to foreign direct investments (FDI) measured using the sum of absolute values of FDI inflows and outflows as a share of Gross Domestic Product (GDP) denoted as FDIGDP and includes equity capital, reinvestment earnings, other long -term capital and short-term capital.

- Openness to gross private capital flows, calculated as the sum of the absolute values of direct, portfolio, and other investment inflows and outflows as a ratio of GDP, and denoted by GPVTFGDP.

\begin{tabular}{|c|c|}
\hline FPET & Percentage overall foreign participation to Equity Turn over \\
\hline FT & \begin{tabular}{ll}
\multicolumn{2}{l}{ Financial Trilemma index representing either } \\
- & MIIPR \\
- & EI/EII \\
- & FOI
\end{tabular} \\
\hline GDP & Kenya's GDP in US dollars millions at market prices \\
\hline $\begin{array}{l}\text { GPVTF } \\
\text { GDP }\end{array}$ & Gross private flows as a percentage of GDP \\
\hline $\begin{array}{l}\text { GPVTK } \\
\text { FLOWS }\end{array}$ & Gross private capital flows in USD given as FDI plus short-term portfolio (in/out) flows absolute terms \\
\hline $\begin{array}{l}\text { GPVTK } \\
\text { FLOWS } \\
\text { GDP }\end{array}$ & $\begin{array}{l}\text { Gross private capital flows in USD as a \% of GDP given as sum of Foreign Direct Investment, Short-term } \\
\text { portfolio (in/out) flows in absolute terms as a percentage of GDP }\end{array}$ \\
\hline INF & Inflation given as the percentage change in CPI \\
\hline INST & Instability as computed by the author in equation 6 \\
\hline M3G & Growth rate of money supply M3 \\
\hline MB & Monetary base (MB) in million US dollars \\
\hline MI & Monetary Integration Index \\
\hline MIIPR & MII based on both Kenya and USD Policy Rates \\
\hline MIITB & MII based on both Kenya's and USD Treasury bills Rates \\
\hline OutputG & Growth rate of GDP \\
\hline $\mathrm{RV}$ & CBK official reserves assets in USD millions \\
\hline RVGDP & Percentage of CBK official reserves as a percentage of GDP \\
\hline TB91 & 91-Treasury bill rate in Kenya \\
\hline $\begin{array}{l}\text { US Policy } \\
\text { Rate }\end{array}$ & FED funds effective rate \\
\hline USTB & 3month US Treasury bill rate \\
\hline
\end{tabular}


Figure 1: Percentage Overall Foreign Participation to Equity Turn Over

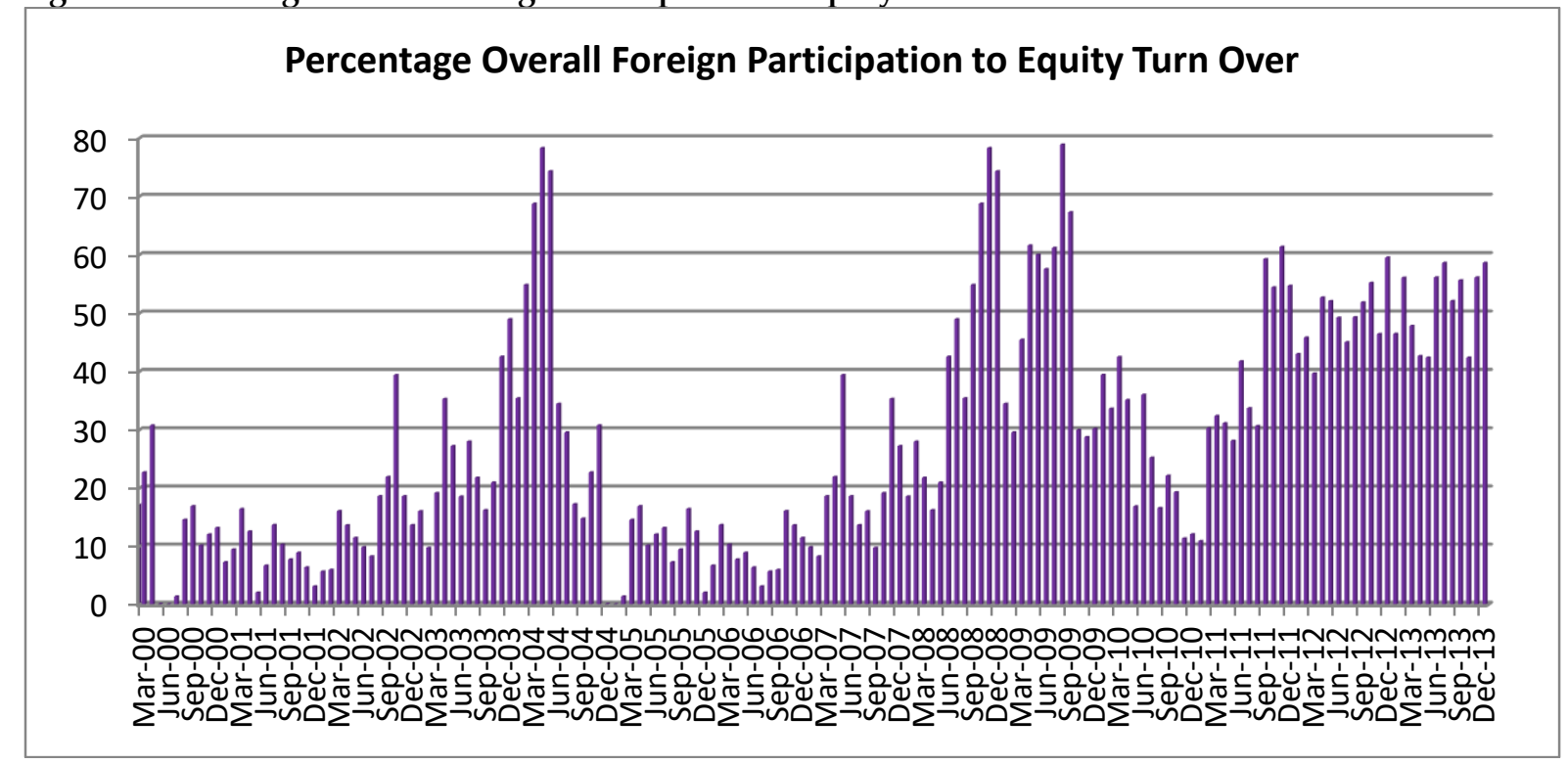

Figure 2: CBK Foreign Exchange Market Interventions in US Dollars Millions A: Sales and Purchases

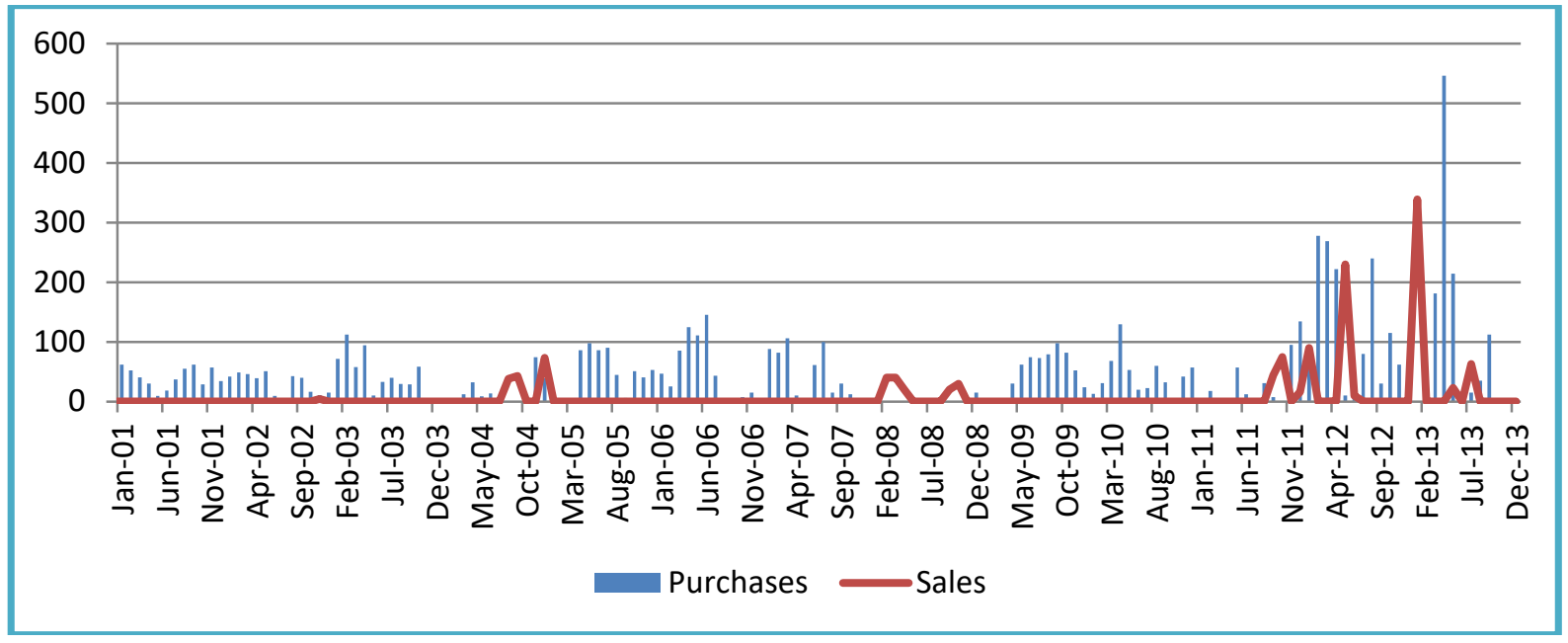

\section{B: Net Purchases}

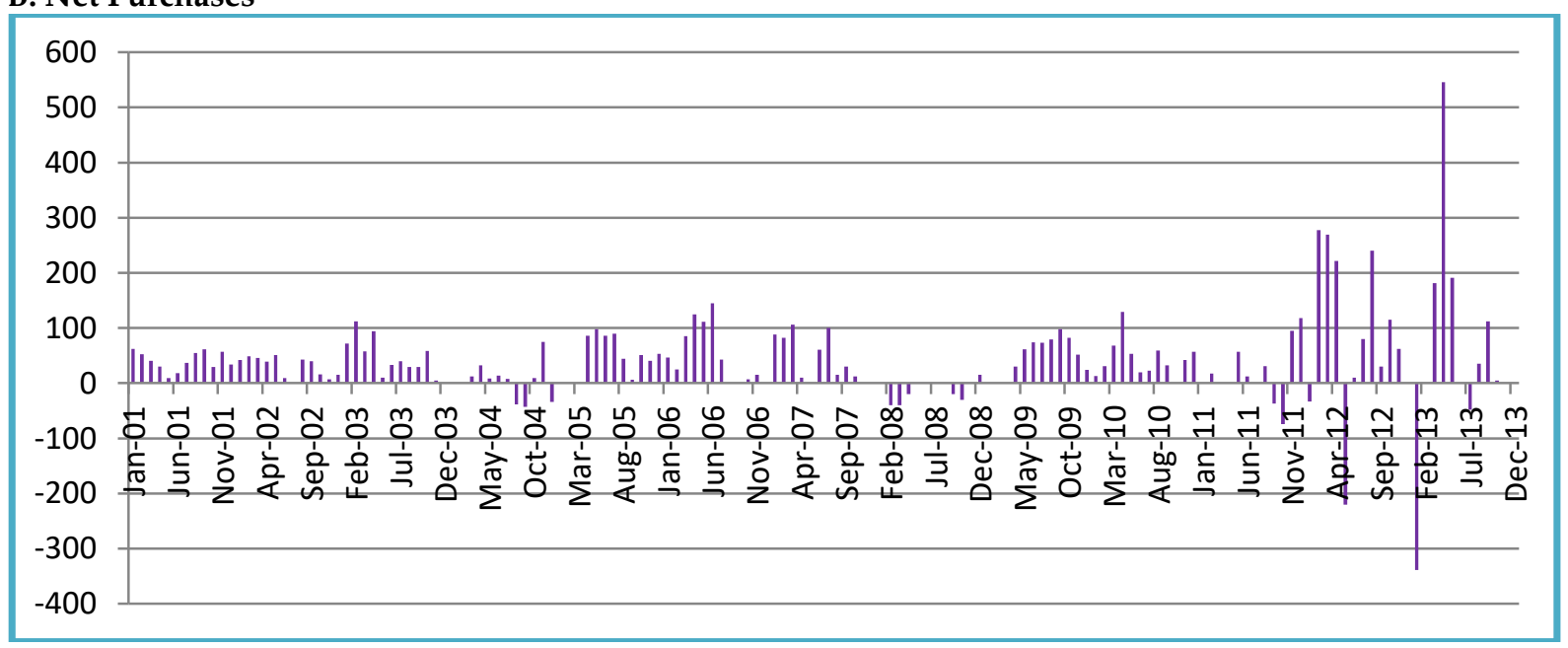


Figure 3: Gross Official Reserves as a Percentage of GDP

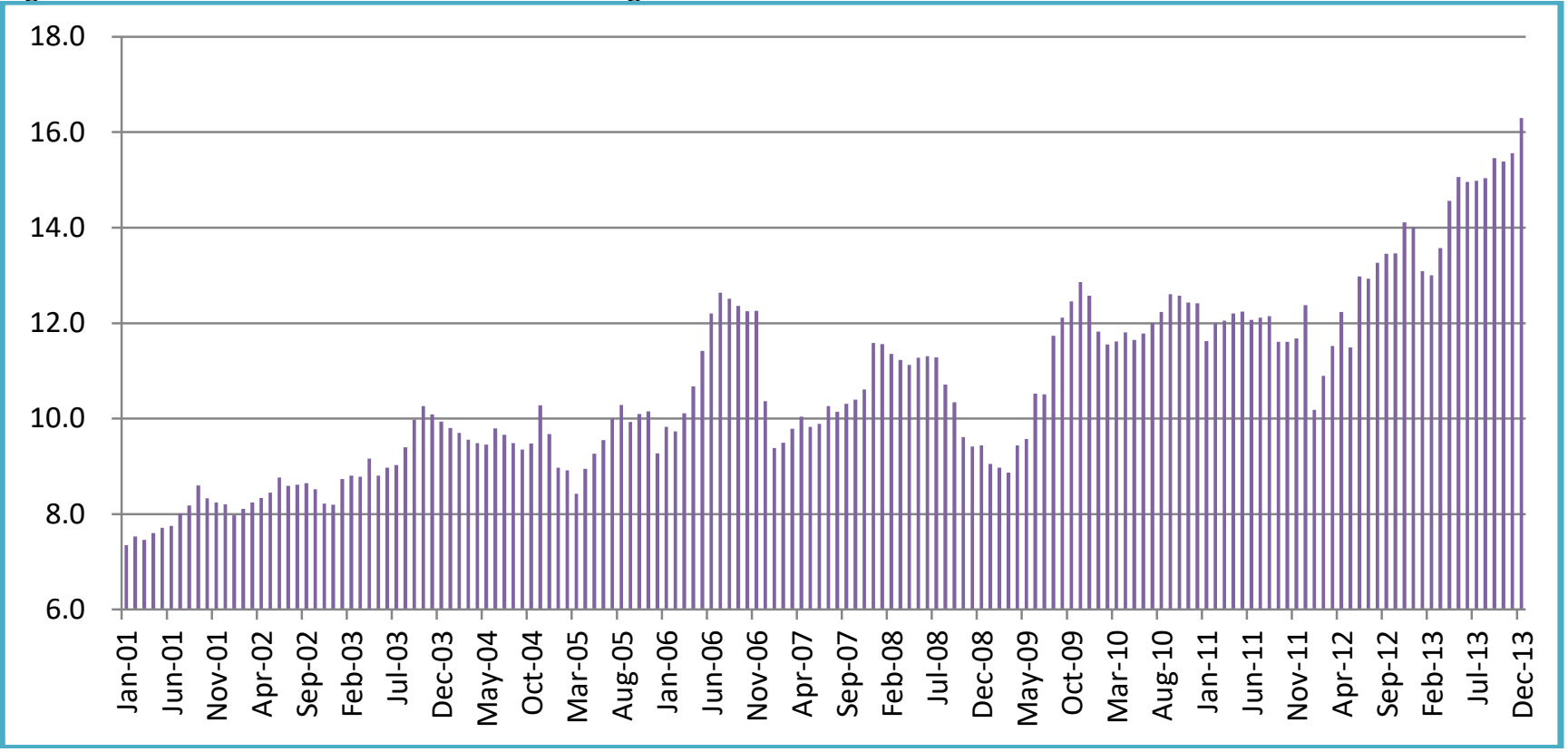

Figure 4: Financial Trilemma and Reserve Accumulation

A: Financial Openness Measured by Ratio of FDI to GDP

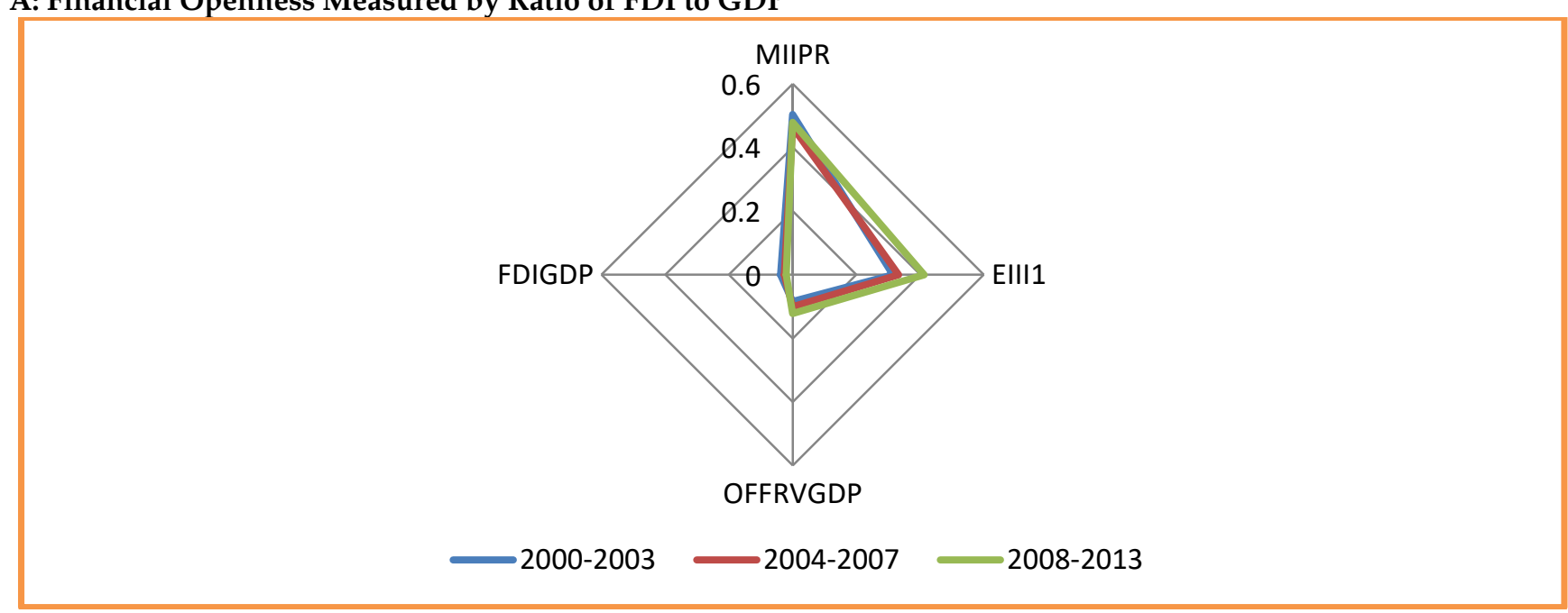

B: Financial Openness Measured by Ratio of Gross Private Capital Flows to GDP

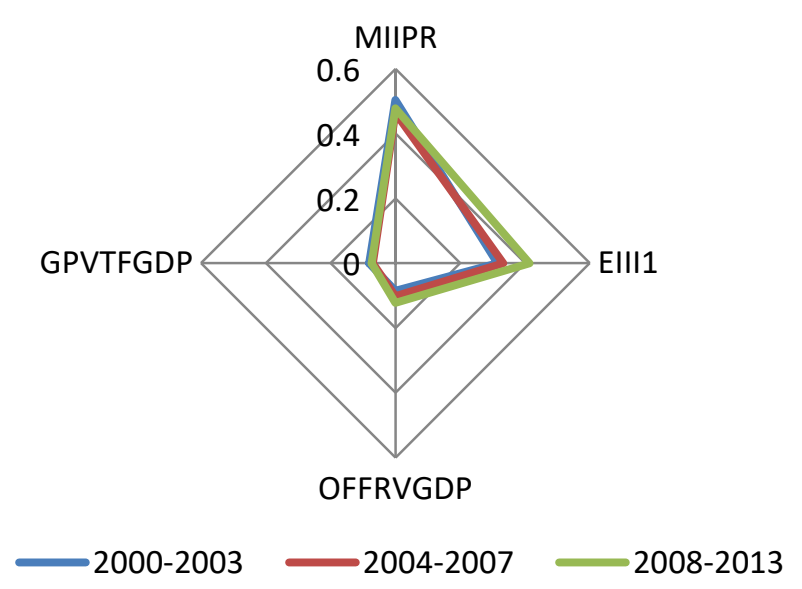




\section{C: Financial Openness Measured by Ratio of Overall Foreign Participation to Equity Turn Over}

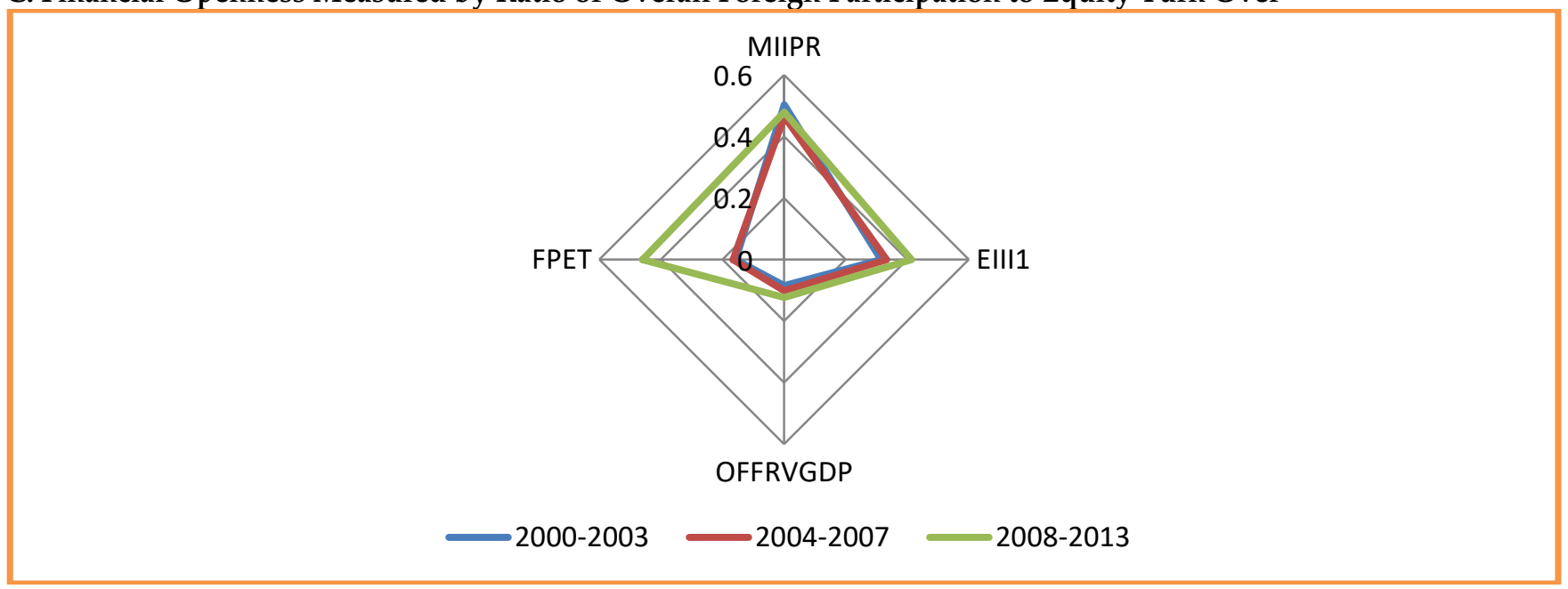

